Mersiha Čaušević, prof.

\title{
NAČINI OBOGAĆIVANJA LEKSIKONA ARAPSKOG JEZIKA
}

\section{Sažetak}

Razvoj jezika je produkt kulturnih $i$ civilizacijskih tekovina njegovih govornika. Arapski jezik se razvijao najprije kroz poeziju i usmena predanja prijeislamskih Arabljana, potom kroz trajno nastojanje da se interpretiraju Kur'an i Hadis, dva osnovna izvora religije islam. Za razvoj jezika potrebne su odredene metode koje odgovaraju strukturi jezika, a u arapskom jeziku one su analogijske (qiyās), i karakteristične su za arapski, kao semitski jezik, jer se fokusiraju ponajprije na etimologiju (išstiqāq), odnosno na etimološku derivaciju, na korijen riječi kao specifikum ovog jezika. Potom slijede paradigmatski oblici $(f, ;)$, takoder prvo zasnovani na korijenu riječi kojem je pridružena afiksacija. Slijedi kontaminacija (naht), preneseno značenje (mağaz), afiksacija uz već postojeću riječ, aneksija ('ị̂āfa), pozajmljivanje stranih riječi (iqtirād) i njihova prilagodba arapskom jeziku (ta'rīb). Svi ovi načini tvorbe riječi doprinose povećanju vokabulara arapskog jezika.

Ključne riječi: metoda, tvorba riječi, derivacija, korijen, paradigma, kontaminacija, arabizacija, preneseno značenje, sufiks.

\section{Uvod}

Arapski jezik ima izuzetno bogatu leksiku. Na razvoj i upotrebu određene leksike utječu različiti faktori, npr. društveno okruženje, zanimanja kojima se bave pripadnici određene zajednice, njihov način života, međusobni odnosi, te odnosi sa pripadnicima drugih zajednica. Pošto je jezik sredstvo komuniciranja među ljudima, kako među pripadnicima iste zajednice, tako i sa drugim i drugačijim članovima zajednica, stalna upotreba jezika iziskuje formiranje novih riječi, stare riječi postaju semantički depletirane, arhaične, javljaju se neologizmi, sinonimi, homonimi, itd. U međusobnoj komunikaciji dolazi do utjecaja jednog jezika na drugi, riječi se prilagođavaju jeziku u koji ulaze na način da zadovolje, koliko god je to moguće, fonetske, morfološke, sintaksičke ili semantičke zahtjeve jezika recipijenta. Također, znanstveni i društveni razvoj utječe na formiranje nove 
leksike. Jezici čiji su govornici napredniji civilizacijski daju, dok podređeniji narodi, odnosno jezici primaju riječi.

Što se arapskog jezika tiče, nesumnjivo je da je jezik Kur'ana (7. st.) utjecao na kasniji razvoj književnog jezika. Tačnije, Kur'an je postulat na osnovu kojeg književni arapski jezik i danas funkcionira i iz kojeg crpi kontinuitet i nepromjenjivost, za razliku od nekih jezika, npr. u kojima je višestoljetnim razvojem jezika došlo do promjene u izgovoru, dok je riječ u svojoj pisanoj formi ostala ista, (engleski, njemački, itd.). Međutim, i prije Objave, jezik Arapa je bio poetski izuzetno razvijen. U Mekki su održavani godišnji sajmovi na kojima su Arapi mogli da prezentuju svoja pjesnička umijeća, a najbolje pjesme su vješane na Kabu, što je očit dokaz da je jezik bio toliko razvijen da su se mogli nadmetati u kreiranju stilskih figura i jezičkom iskazu općenito.

Osim poezije i kur'anskog teksta, na razvoj arapskog jezika utjecalo je i interpretiranje Poslanikova a.s. govora - hadisa, ${ }^{1}$ ali i određen dio proze prenošene usmenim putem, kao što su: govori (hutbe), poslovice, oporuke, itd. ${ }^{2}$

Širenjem islama javila se i potreba za značajnijim proučavanjem arapskog jezika, i to vrlo brzo. Već u prvom stoljeću islama Abū al'Aswad al-Dualī (umro 67. po H.) smatra se začetnikom arapske gramatike. ${ }^{3}$ Razvoju lingvistike značajan doprinos dala su ova tri faktora: vjerski (pravilno čitanje, razumijevanje i interpretiranje Teksta), nacionalni (direktan susret sa nearapskim narodima, kulturama i civilizacijama: sasanidskom, grčkom, rimskom, indijskom, staroegipatskom...), te politički (emevijski arapski halifat). ${ }^{4}$

Širenje islama je isto tako uvjetovalo i razvoj novih riječi, $i$ to na neki od sljedećih načina:

\footnotetext{
${ }^{1}$ Șubḥ̄ Ṣāliḥ, Dirāsāt fì fiqh al-lug̉a, Dār al'ilm li al-malāyīn, Bayrūt, 1979., str.55

${ }^{2}$ Muhtār, 'Umar 'Aḥmad, Al-Baḥt al-lugiawiyy 'inda al-'arab, 'Ālam al-kutub, alQāhira, 1988., str.17-56

${ }^{3}$ Jaroslav Stetkevych, The Modern Arabic Literary Language: Lexical and Stylistic Developments, Georgetown University Press, Washington D.C., 2007., str. 2.

${ }^{4}$ Mustafa Jahić, Arapski jezik u islamskim naukama: povezanost i međusobni utjecaji, El-Kalem : GHB biblioteka, Sarajevo, 2012, str. 134-144
} 


\section{Qiyās (analogija)}

Analogija je način koji se često primjenjuje pri tvorbi novih riječi. Stetkevych tvrdi da analogija najvjerovatnije ima najznačajniju ulogu u derivaciji u arapskom jeziku, čak i danas. ${ }^{5}$ On također tvrdi da je vitalni princip qiyāsa učinio mogućim derivaciju (ištiqāq) i tvorbu složenih formi (naht), kao i arabizaciju prilagođenu duhu arapskog jezika (ta' $r i \bar{b}){ }^{6}$

Iz ove izjave zaključuje se da je analogija princip na kojem su izgrađeni načini tvorbe riječi u arapskom jeziku. Također, analogija je imala široku primjenu и izvođenju imenica iz glagola, glagola iz imenica $i$ adaptiranju stranih riječi na paradigme arapske gramatike. Primjenjivana je i u ustanovljavanju paradigmi, zbog čega su brojni klasični filolozi smatrali da se cjelokupna gramatika može poistovjetiti sa analogijom. Siroku primjenu je imala u svim fazama arapskog jezika u okrilju islama. ${ }^{7}$

\section{Ištiqāq (derivacija)}

Derivacija u arapskom jeziku podrazumijeva etimološku tvorbu riječi. Gramatičari se slažu sa al-Ğinnijevom podjelom derivacije na tri vrste: ${ }^{8}$

1. Al-ištiqāq al-şagìr - (mala derivacija), derivacija po kojoj od istog korijena nove riječi nastaju afiksacijom, i to:

- prefiksima, npr. iz korijena s, l, m: 'AS-lama (predati); MU-slim (predan /Bogu/, musliman)

- infiksima, od istog korijena: 'is-TA-lama (primiti; dobiti)

- afiksima, silm-IYY (pacifist)

\footnotetext{
${ }^{5}$ Ibid., str. 3.

${ }^{6}$ Ibid., str. 4. Tekst u originalu glasi: ...the vital princip of qiyās which made possibal derivation (ishtiqāq) and creation of compound forms (naht), as well as arabisation according to the spirit of Arabic language (ta'rīb)...

7 Kico, Mehmed, Arapska jezikoslovna znanost, općelingvistička utemeljenja $i$ specifična određenja, FIN, Sarajevo 2003., str. 234.

${ }^{8}$ Ibid., str. 235.
} 
- njihovom kombinacijom sal-Ā-m-A (spas); ISTI-sl- $\bar{A}-\mathbf{m}$ (pokoravanje).

Jaroslav Stetkevych ovu derivaciju naziva jednostavnom, te navodi kakoje u ovom procesu kreiranja novih riječi jednostavna derivacija imala najprominentniju ulogu. ${ }^{9}$

Sa ovom tvrdnjom slaže se i Șubḥ̄ Șāliḥ: Mala derivacija je najviše و الاشتناق الاصغر اكثر انواع - prisutna vrsta derivacije u arapskom jeziku 10 الاشتقاق ورودا في العربية

Teufik Muftić ovakve načine tvorbe dijeli na:

- alternaciju (međusobno smjenjivanje kratkih vokala),

- prolongaciju vokala,

- geminaciju, tj. udvajanje radikala i(li) drugih konsonanata,

- afiksaciju (upotrebu nekorijenskih sufiksa),

- reduplikaciju radikala ili čitave osnove. ${ }^{11}$

Kao primjere za ovo možemo navesti, npr. za alternaciju: yaktubu (on piše), yuktabu (piše se), prolongaciju vokala: kataba ( pisao je), kātaba (dopisivali su se), geminaciju: galaqa - zatvoriti, gallaqa - pozatvarati, afiksaciju: fataḥa - otvoriti, miftāh - ključ, te reduplikaciju: hudhud (pupavac).

2. Al-ištiqāq al-kabīr - (velika derivacija), qalb - (premetanje), ova metoda predstavlja zamjenu konsonanata, npr. triletera sastavljena od konsonanata $\mathbf{b}, \breve{\mathbf{g}}$ i $\mathbf{r}:^{12}$

Ako imamo triliteru, moguće je ustanoviti, npr., šest kombinacija u I vrsti glagola ${ }^{13}$.

\footnotetext{
9 Jaroslav Stetkevych, The Modern Arabic Literary Language: Lexical and Stylistic Developments, Georgetown University Press, Washington D.C., 2006., str. 7.

${ }^{10}$ Șubḥī Ṣāliḥ, Dirāsāt fi fiqh al-luğa, Bayrūt, 1979., str.174.

11 Teufik Muftić, Gramatika arapskog jezika, Ljiljan, Sarajevo, 1998., str.172. i dalje.

12 Ibid., str. 159.

${ }^{13}$ Primjere sa $s, l, m$, gdje citira Ibn al-Ḡinnīja vidjeti kod: Șubḥī Ṣāliḥ, Dirāsāt fĩ fiqh al-luga, str.186.
} 


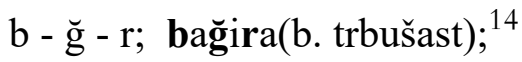

b - r - ğg; bariğa (imati u izobilju /jela, pića/);

$\breve{g}$ - r - b ; ğariba (biti šugav);

$\breve{\mathrm{g}}$ - b - r; ğabara (zarasti /slomljena kost/);

r - ğ - b; răgaba (postidjeti se);

r - b - ğ ; rabuğa (biti glup);

Ove kombinacije se odnose samo na konsonante, jer pomoću alternacije može se postići više značenjskih kombinacija, npr. od korijena $\mathrm{r}-\breve{g}-$ b imamo, pored gore navedenog primjera ră̆-A-ba i rağ-I-ba (bojati se; osjećati strahopoštovanje).

3. Al-ištiqāq al-'akbar-(najveća derivacija), 'ibdāl-dodavanje trećeg konsonanta na bilitere, odnosno ako se al-ištiqāq al-kabir temelji na premetanju konsonanata, jasno je da se al-ištiqāq al- 'akbar temelji na gamjeni istih - واذا كان الاشتقاق الكبير يقوم علي القلب فمن الواضح ان الاشتقاق الاكبر

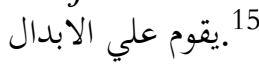

Bilitera ima samo 29 u arapskom jeziku. Najviše je trilitera, a oni su se razvili iz bilitera. ${ }^{16}$ Pošto je teško utvrditi kad i na koji način je došlo do tog razvoja, i šta je bio prvobitni oblik sadašnjeg trilitera, nemali broj glagola ima ista dva korjenita konsonanta, dok se treći razlikuje, npr. lahafa (prekriti); laḥiqa (sustignuti), ili warita (naslijediti); warida (doći), itd. Ovakvi glagoli često imaju slična značenja, kao što je slučaj sa prethodno navedenim primjerima: naslijediti znači doći iza nekoga.

Derivacija od postojecih arapskih korijena oduvijek je smatrana najprirodnijim načinom obogaćivanja jezika. Arapski se zove jezikom ištiqāqa, a ova sposobnost jezika da se obogaćuje iz vlastite jezgre daje

14 Značenja preuzeta iz: Teufik Muftić, Arapsko-bosanski rječnik, Rijaset IZ u BiH, Sarajevo, 1997.

15 Șubḥ̄ Ṣāliḥ, Dirāsāt fi fiqh al-lugia, str.212. Ovdje autor ukazuje i na fonetske karakteristike određenih harfova prilikom 'ibdāla.

16 Teufik Muftić, Gramatika arapskog jezika, str.155. i dalje. 
mu rijetku homogenezu, koja je ponos arapskih pisaca i filologa i koju revnosno čuvaju. ${ }^{17}$

\section{Paradigme}

Za tvorbu riječi u arapskom jeziku koriste se oblici za koje se upotrebljvaju tri konsonanta, čije je osnovno značenje raditi, činiti. Ti konsonanti su: fā, 'ayn i lām, i oni se najčešće koriste za obilježavanje paradigme koja je obrazac za tvorbu riječi.

Osnovna paradigma je fa 'ala, i njome se označava perfekat, npr. da bi se dobio glagol kataba, kad se govori o paradigmama, ekvivalent mu je upravo fa' ala. Isto je i za dahaba (ići), darasa (učiti), itd. Naravno, ne dolaze svi glagoli na ovu paradigmu. Pošto se glagoli dijele po vrstama, svaka od njih ima zasebne oblike koji se koriste prilikom njene upotrebe. Nabrojani primjeri spadaju u I vrstu glagola, a koja se opet dijeli u razrede (njih šest), tako da, npr. četvrti razred I vrste u perfektu dolazi na paradigmu fa ila, npr. 'alima (znati), itd. ${ }^{18}$

Postoje i proširene glagolske vrste, a one dolaze na različite paradigmatske oblike, npr. ako je u I vrsti glagol șadaqa (govoriti istinu), u II vrsti, a koja se manifestira udvajanjem srednjeg radikala (korjenitog suglasnika), gdje je paradigma fa' "ala, postaje saddaqa (učiniti vjerodostojnim; ovjeriti), tj. postaje dvostruko prelazan, dok je u III glagolskoj vrsti, koja nastaje produžavanjem vokala iza prvog korjenitog suglasnika, što znači da je ovdje paradigma fā'ala, postaje șādaqa (prijateljevati /s nekim/), ima značenje reciprociteta, itd.

\footnotetext{
${ }^{17}$ Jaroslav Stetkevych, The Modern Arabic Literary Language, Georgetown University Press, 2007., str. 7. Originalni tekst navoda: Derivation from existing Arabic roots has always been considered the most natural way of growth for the language. Arabic has been called the language of ishtiqāq, and this ability to grow from its own essence has given the language its rare homogeneouness, which is the pride of arab writers and philologists and which they are zealous to protect.

18 Vidjeti više u: Teufik Muftić, Gramatika arapskog jezika, str. 285. I ovdje se primjenjuje alternacija.
} 
Arapski jezik poznaje XV vrsta glagola. ${ }^{19}$ Svaka od ovih vrsta dolazi na različite oblike paradigmi, a svi ti oblici doprinose tvorbi riječi i razvoju vokabulara.

Isto je i sa participima. Neki participi se poimeničavaju, pa, pored osnovnih participnih značenja imamo, npr. od glagola šahana u I vrsti (napuniti) particip aktivni šăḥin (punjač), ili u III glagolskoj vrsti od glagola qāwama (suprotstaviti se) muqāwim (otpornik), ili u X vrsti od glagola istaqbala (primiti) mustaqbil (prijemnik), itd.

Ovi primjeri su nastali iz glagola i česti su, dok su glagoli nastali od imenica znatno rjeđi, npr. od dahab (zlato) nastalo je dahhaba (pozlatiti), i sl.

Glagolske imenice ili infinitivi (mașdar $)^{20}$ prilikom tvorbe riječi toliko su frekventni da služe čak i kao nosioci značenja: ako uzmemo za primjer glagol wașala, a ako nam je potrebno njegovo značenje povezati, spojiti, tad upotrebljavamo glagolsku imenicu (infinitiv) wașl ili drugi oblik șila. Međutim, ako nam je potrebno značenje doći, stići, tad koristimo wuṣūl, wusla ili șila. ${ }^{21}$ Ovdje se vidi da se jedan od maṣdara (șila) može upotrebljavati za oba primjera, što upućuje na zajednički korijen riječi i semantičku povezanost.

Ali, isto tako, ne treba zanemariti ni prijedloge, koji su često nosioci značenja u arapskom jeziku. U gore navedenim primjerima uz prvu spomenutu glagolsku imenicu (infinitiv) dolazi prijedlog bi (sa) : wașala bi, dok uz drugi ide 'ilā (do): wașala 'ilāa.

Upotreba različitih prijedloga može dovesti čak do potpune promjene značenja, odnosno do suprotnog značenja, npr. uz glagol da ' $\bar{a}$ (pozivati) ako upotrijebimo prijedlog li, njegovo značenje je moliti za (nekoga), dok da 'à 'alā znači moliti protiv (nekoga), proklinjati. Arapski jezik, pored glagolske imenice, ima još paradigmatskih oblika za tvorbu.

\footnotetext{
${ }^{19} \mathrm{O}$ proširenim vrstama i njihovim značenjima i upotrebi vidjeti: Ibid,. str. 310. i dalje, a paradigme glagolskih oblika u tabelama, str. 353-389.

${ }^{20}$ Teufik Muftić daje 160 različitih oblika glagolske imenice I vrste glagola. Vidjeti u: Ibid., str. 245-247.

${ }^{21}$ Upotreba maṣdara preuzeta iz: Teufik Muftić, Arapsko-bosanski rječnik, str. 1643.
} 
Neke od njih su imenice oruđa, ili analogijske derivacije iz konkretnih imenica, itd. Navest ćemo neke primjere: ${ }^{22}$

fi'āl - 'irad (kresivo)

fā'ila-țà'ira (avion)

$f_{\bar{a}}$ ' $\bar{u} l-s \bar{a} t \bar{u} r$ (mesarski nož)

fa' 'āla-darrāğa (bicikl)

mif'al - minğal (srp)

mif'āl-mihrāa $b$ (mihrab)

mif'ala - miknasa (metla)

fa' $\bar{a} l-t a y y \bar{a} r(\text { pilot })^{23}$

maf'al - mal'ab (igralište)

maf'il - masğid (džamija)

maf'ala - madrasa (škola)

fu'āl - șudā' (glavobolja)

fa'āla - ġassāla (mašina za veš)

tafā'ul - taḍāmun (solidarnost)

Također, mnogobrojni su i načini tvorbe nepravilne množine. ${ }^{24}$ Nepravilna množina je toliko česta da neka imena (imenice, pridjevi i sl.), pored pravilne (npr. množina imenice 'āmil - radnik je 'āmilūna radnici) imaju i nepravilnu ('ummāl - radnici) množinu. Isto tako, nepravilna množina ove imenice 'awāmilu mijenja značenje ove riječi, tako da 'āmil mn. 'awāmil znači faktor, mn. faktori. Dakle, i množine mogu biti nosioci značenja. Isto tako, ako za imenicu bayt (kuća) mn. buyūt (kuće) koristimo množinu 'abyāt onda je značenje ove riječi u jednini stih, odnosno u množini stihovi. Neka imena imaju više oblika nepravilnih množina, što znači da je arapski jezik razvio izuzetnu

${ }^{22}$ Detaljnije vidjeti u: Teufik Muftić, Gramatika arapskog jezika, str.178 - 196.

${ }^{23}$ Ovaj i primjeri koji slijede preuzeti iz: Hajrudin Hodžić, Arapski vjersko-pravni termini $u$ islamu, neobjavljena doktorska disertacija, odbranjena 26.11.2014. na Filološkom fakultetu u Beogradu, str. 50.

${ }^{24}$ Teufik Muftić, Gramatika arapskog jezika, str.178 - 196., str. 212 i dalje. 
sposobnost prilagođavanja riječi bilo kojoj paradigmi. Dalje, postoje i množine množine, npr. od imenice yad (ruka) množina je 'aydin (ruke), dok je njena množina množine 'ayādin (ruke), itd. ${ }^{25}$ Ili, množina imenice bayt (kuća) je buyūt (kuće), dok je množina množine buyūtât ${ }^{26}$ (kuće). ${ }^{27}$

\section{Kontaminacija (naḥt)}

Haplologija ili kontaminacija je sažimanje dviju ili više riječi u jednu. Za razliku od derivacije, to je operacija jezičkog skraćivanja, pri kom se dvije srodne ili nesrodne riječi, čak $i$ čitave rečenice sažimaju u jednu riječ. Ovakve riječi imaju uglavnom oblik glagola $i$ sastoje se od četiri kosonanta. $^{28}$ Ova definicija jasno objašnjava ovaj način tvorbe. Primjeri za naḥt su:

- hamdala ${ }^{29}$ - reći al-ḥamd li Allāh,

- basmala - reći bismi Allāh al-Raḥmān al-Raḥīm, itd.

Ovakvi primjeri rijetki u savremenom jeziku, npr. qasharra je kontaminirano od qās al-ḥarr - mjeriti temperaturu. ${ }^{30}$, odnosno, prava složena imena su uvijek bila rijetka u arapskom, limitirana na nekoliko naziva mjesta, te brojeve 11 - 19 i stotice... Ono što se u zapadnim jezicime pojavljuje kao složenica, normalno se izražava genitivnom vezom... ${ }^{31}$

${ }^{25}$ Ibid., str. $230-231$.

${ }^{26}$ Ovdje je na nepravilnu množinu dodana pravilna množina ženskog roda.

27 El-Said Badawi, Michael G. Carter, Adrian Gully, Modern Written Arabic, a Comprehensive Grammar, Routledge, USA and Canada, 2004., str. 767.

${ }^{28}$ Mehmed Kico, Arapska jezikoslovna znanost..., str. 236.

${ }^{29}$ Vidjeti više u: Ibid., str. 236, ili u: Teufik Muftić, Gramatika arapskog jezika, str. 164.

${ }^{30}$ Ibid., str. 164.

31 El-Said Badawi, Michael G. Carter, Adrian Gully, Modern Written Arabic: A Comprehensive Grammar, Routledge, USA and Canada, 2004., str.751. Tekst u originalu izgleda ovako: True compound nouns have always been rare in Arabic, being limited to a few place names andthe numbers 11-19 and hundreds... What usually appears in Western languages was normally expressed by annexiation... 
Međutim, metoda kontaminacije se, pored genitivne veze, ipak koristi, i dijeli se na: ${ }^{32}$

- Čisti naḥt

kahrațas - elektromagnetizam; riječ nastala od kahraba (elektrizirati) i mag்nātīs (magnet)

baytaqāfi - međukulturalan; nastalo od bayna (između) i taqāfa (kultura), itd.

- Spajanje dvije riječi u jednu

ra'simāl (kapital); riječ nastala od ra's (glava) i (māl) imetak.

- Dodavanje sufiksa - $n$

$\dot{g} a r b \bar{a} n a$ - vesternizacija, uvođenje zapadnjačkih običaja; nastalo od algarb (Zapad) i sufiks $-n$.

- Dodavanje stranog afiksa na arapsku imenicu

șawtìm - fonema; nastalo od șawt (glas) i engleskog sufiksa -eme.

Naht se koristi u tvorbi znanstvenih termina, npr. lāma' (dehidrirati), od $l \bar{a}$ (ne) i $m \bar{a}$ ' (voda), a i u medicini: wağa 'ada (gastritis), od wă̆ ' (bol) i $m i$ 'da (želudac).

Zatim, uz jednu riječ, npr. pridjev, možemo dodati prefiks za negaciju lāa pa uz 'iğtimā'iyy (društven) dobijemo riječ suprotnog značenja: lā 'iğtimā'iyy (nedruštven), ili 'insāniyy (ljudski) i lā 'insāniyy (neljudski), a uz imenicu dodajemo određeni član ispred negacije: al lā 'aqlāniyy (iracionalnost, nerazboritost), al lā markaziyya (decentralizacija), itd. ${ }^{33}$

Postoje i drugi oblici koji služe za tvorbu negacije: ${ }^{34}$

- 'adam - 'adam al-ta'āwun - nesolidarnost; 'adam riḍa (nezadovoljstvo),

- 'adīm - 'adīm al-nazīir - neuporediv.

\footnotetext{
${ }^{32}$ Ibid., str. 751-752.

33 Ibid., str. 755.

${ }^{34}$ Vidjeti više u: Ibid., str. 754. i 755.
} 
Zatim, ime $\dot{g} a y r$, koje inače znači drugi upotrebljava se isto za negaciju drugog člana aneksije:

- $\dot{g} a y r$ - $\dot{g} a y r$ al-mutawaqqi` - neočekivan; naspram mutawaqqi'očekivan

Ili, qābil što znači sposoban (za) također se koristi uz jednu od imenica koje služe za odrično značenje:

- gayr qābil li al-naql-neprenosiv

Teufik Muftić navodi po primjer za svaku upotrebu negacije drugog člana genitivne veze, npr. sū'u al-tafāhum (nesporazum); șa 'b al-qirāa (nečitak), itd. ${ }^{35}$

Pored ovih, koriste se i (ovdje u potvrdnoj konotaciji) šibh, npr. šibh rasmiyy (poluslužben), ili riječ nafs (isti): fì nafs al-šāri' (u istoj ulici), qābil li al naql (prenosiv), itd.

\section{Preneseno značenje ('al-mağāz)}

Upotreba stilskih figura, pogotovo metafore, također se koristi kao jedan od načina obogaćivanja leksikona.

Da bi se shvatilo preneseno značenje neke riječi, potrebno je da postoji veza između osnovnog i figurativnog značenja, te da postoji kontekst koji sprječava doslovno razumijevanje značenja. ${ }^{36}$

Ovaj prelazak riječi iz osnovnog u preneseno značenje (تعدي الكلمة من izuzetno je čest u književnosti, gdje upotreba stilskih figura, npr. alegorije 'arị̣ al-wisāda, (dosl. onaj čiji je jastuk širok) - bezbrižan ${ }^{38}$ ima najčešće estetski efekat.

Međutim, ako pogledamo primjere poput:

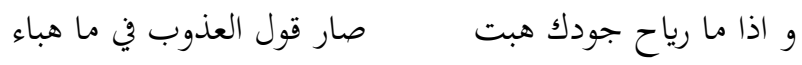

\footnotetext{
35 Teufik Muftić, Gramatika arapskog jezika, str. 510.

${ }^{36}$ Hajrudin Hodžić, Arapska vjersko-pravna terminologija u islamu, neobjavljena doktorska disertacija, odbranjena 26.11. 2014. na Filološkom fakultetu u Beogradu, str.51.

${ }^{37}$ Al-Sakākī, Miftāḥ al'ulūm, Dār al-risāla, Bag̉dād,1982., str. 595.

${ }^{38}$ Munir Mujić, Tropi i figure u arapskoj stilistici, Sarajevo, 2011., str. 127.
} 
Kad vjetrovi darežljivosti tvoje zapušu (habbat)

Riječi onih što grde te postanu kao prašina uskovitlana (habā') ${ }^{39}$

vidjet ćemo da se unutar jezika traga za riječju koja se može upotrijebiti $\mathrm{u}$ datom kontekstu, ako ne u semantičkom, bar u fonetsko-morfološkom pogledu, kao što su glagoli habata i habā' iz navedenog primjera. Upravo to traganje unutar jezika da bi se postigao neki estetski efekat $\mathrm{i}$ zadovoljile potrebe žanra, kao što su rima i ritam, dovodi do bogaćenja leksikona.

\section{Afiksacija u tvorbi}

\section{Sufiks -iyy}

Ovim sufiksom se najčešće izražava pripadnost (niṣba), ali ima i pridjevsku funkciju, npr. madaniyy (medinski, civilizacijski) od hadāta (modernizam) hadātiyy (modernist), ili od dahab (zlato) dahabiyy (zlatni), itd.

Ponekad se na sufiks -iyy dodaje još jedan sufiks $-a$, npr. istiqlāl (nezavisnost), istiqlāliyy (nezavisan), dok istiqlāliyya (sa oba sufiksa) postaje imenica i znači isto što i prvotna imenica istiqlāl (nezavisnost).

\section{Sufiks -āwī ili -awī}

Koristi se na isti način kao i -iyy. Primjeri: būsnawiyy (Bosanac, Bošnjak; bosanski), tarbiya (odgoj), tarbawiyy (odgojni).

Postoje i pseudoafiksi, kao što su:

- mā warā'a - mā warā'a al-țabī'ah - metafizika

- niṣf - niṣf al layl - ponoć

- 'abr - 'abr qawmiyy - transnacionalan,

- ba'da - ba'd al-ḥarb - postratni, itd.

Kunya je jedna od specifičnosti arapskog jezika. Njome se pomoću izraza za bliže rodbinske odnose genitivnom vezom dolazi do novih značenja, npr. pomoću $a b$ (otac): $a b$ al-bašar - Adem (otac

${ }^{39}$ Munir Mujić, Tropi i figure u arapskoj stilistici, Sarajevo, 2011., str.195. 
čovječanstva); abū al-bașīr (slijep, dosl. otac onog koji vidi) ${ }^{40}$; abu a' $m \bar{a}$ (krtica, dosl. otac slijepoga); abū mālik (orao, dosl. otac vlasnika), pomoću umm (majka): umm al-malik (kraljica-majka); umm sulaymān (lasica, dosl. majka Sulejmana); umm 'arba'a (stonoga, dosl. majka četvorke); umm al-dunyā (Kairo, dosl. majka Svijeta); pomoću ah (brat): ah al-ğūd (darežljiv, dosl. brat dobrote), itd. ${ }^{41}$

Genitivna veza se često koristi u tvorbi riječi, u kunyi, kod gore nabrojanih načina tvorbe pomoću nekih imenica i pridjeva koje dolaze kao prvi član genitivne veze. Međutim, imamo i tzv. „okamenjene genitivne veze“ 42 a njihov prvi član su riječi koje prvobitno označavaju neke osobe: 'ahl (ljudi); imru' (muškarac); $\underline{d} \bar{u}$ (vlasnik); halīf (saveznik); șạhib (drug), itd. Neki primjeri za okamenjene genitivne veze su: 'ahl al-ḥikma (mudraci); halīf al nādā (darežljivac); $\underline{d} \bar{u} m \bar{a} l$ (bogataš), itd. ${ }^{43}$ Pored ovoga, tvorbom riječi genitivnom vezom možemo postići i značenja totaliteta, količine, učestalosti, neodređenosti, sličnosti, $i d r .^{44}$

Npr. za postizanje totaliteta koristi se imenica kull, i uz određenu genitivnu vezu znači cijeli, dok uz neodređenu znači svi, svaki. Tako imamo kull al madina (cijeli grad), dok je kull madīna (svaki grad). ${ }^{45}$

\section{Posuđivanje ('iqtirād) i arabizacija (ta'rīb)}

Jedan od načina tvorbe riječi i obogaćivanja leksikona jeste i posuđivanje stranih riječi. Riječi koje ja arapski jezik preuzeo iz drugih jezika nazvane su arabiziranim riječima (al-kalimāt al-mu'arraba), a sam proces preuzimanja na takav način nazivan je arabiziranjem (alta'rīb). To znači da su riječi uvedene u arapski jezik bile prilagođene naravima arapskoga jezika, njegovom glasovnom sistemu, strukturi $i$

\footnotetext{
${ }^{40}$ Ovdje se vidi upotreba kunye u prenesenom značenju (onaj koji vidi), suprotnom doslovnom (slijep).

41 Teufik Muftić, „Osobenosti upotrebe 'kunye'“, Prilozi za orijentalnu filologiju, 27/1977., Orijentalni institut u Sarajevu, Sarajevo, 1979., str. 133 - 163.

42 Teufik Muftić, „O semantici arapskog idafata“, Prilozi za orijentalnu filologiju, 3233, 1982-83, str. 1-16.

${ }^{43}$ Vidjeti detaljnije primjere u: Ibid., str. 10.

44 Teufik Muftić, Gramatika arapskog jezika, str. 508. i dalje.

${ }^{45}$ Vidjeti više u: Ibid., te u „O semantici arapskog idafata“, Prilozi..., str. 9.
} 
načinu tvorbe novih riječi. ${ }^{46}$ Jaroslav Stetkevych arabizaciju (ta 'rīb), pozivajući se na Al-Maghribīja, povezuje sa nazivom al tağannus, odnosno asimilacijom stranog vokabulara. ${ }^{47}$

Proces prevođenja riječi iz jednog jezika u drugi također utječe na bogaćenje leksike. Iz modaliteta prevođenja koji nalaze mjesto među primjenjivanim principima u procesu dopunjavanja arapske leksike, Teufik Muftić navodi: prihvatanje tuđih riječi (al-isti‘āratu) $i$ opisno adaptiranje (al-iqtibāsu). Ibrahim Aniss, jedan od najistaknutijih modernih lingvista, tvrdi da među principima obogaćivanja arapske leksike putem prevođenja istaknuto mjesto pripada $i$ : posuđivanju (aliqtirāọu) $i$ djelomičnom adaptiranju (al-naḥtu). ${ }^{48}$

$\mathrm{Na}$ početku smo govorili o derivaciji $\mathrm{u}$ arapskom jeziku, o paradigmama, itd. Strane riječi koje su ulazile u arapski jezik, ako je ikako bilo moguće, stavljane su u odgovarajuću paradigmu kako bi udovoljile zahtjevima arapskog jezika.

Npr. od engleske riječi „oxide“, nastala je arapska riječ „ūksada“ (oksidirati). ${ }^{49}$ Dakle, riječ je stavljena u osnovnu paradigmu, fa 'ala, pa je $\boldsymbol{f}$ supstituirano sa $\boldsymbol{k}$, ' sa $\boldsymbol{s}$, te $\boldsymbol{l}$ sa $\boldsymbol{d}$. Na ovaj način dobijena je glagolska osnova, i glagol je sad „spreman“ za konjugaciju. Sad možemo analogijom formirati i participe, aktivni: mūksid (sredstvo za oksidiranje); particip pasivni: müksad (oksidiran), itd. Imenica nastaje dodavanjem okruglog ta na kraju riječi: $\bar{u} k s i \bar{d} d a$ (oksidacija), itd. Neke imenice nisu mogle biti preobličene u obrazac tvorbe riječi u arapskom jeziku, tako da su one ostale „neprilagođene“, npr. bībliyuğrä́fiyā (bibliografija), a to su najčešće imenice sa po pet ili više konsonanata. Neke imenice pišu se dvojako: tiknoloğiya ili tiknoloğiyya (tehnologija). ${ }^{50}$ Ova nedosljednost u pisanju kod stranih naziva je učestala pojava u arapskom jeziku, npr. Turkiya / Turkiyā (Turska),

\footnotetext{
${ }^{46}$ Mehmed Kico, Arapska jezikoslovna znanost..., str. 237.

47 Jaroslav Stetkevych, The Modern Arabic Literary Language: Lexical and Stylistic Developments, str. 6.

${ }^{48}$ Mehmed Kico, Ogledi o poetici prevođenja: u svjetlu iskustava o arapskome jeziku, str. 138.

49 El-Said Badawi, Michael G. Carter, Adrian Gully, Modern Written Arabic: A Comprehensive Grammar, str. 741.

${ }^{50}$ Ibid., str. 742.
} 
zatim neka vlastita strana imena, npr. Tümās / Tomas (Thomas), itd. Ponekad postoji i domaća i strana riječ u upotrebi, npr. ūtill, funduq, lūkanda, nazl (hotel) ${ }^{51}$, ili tabīb, duktūr (doktor), itd. Također, često postoje i parovi termina od kojih je jedan stranoga, a drugi ,,domaćeg “ porijekla (obično terminološki neologizam): npr. arapski (po Petračeku) tilifün , telefon“ ili hätifun ,,telefon “. 52

\section{Zaključak}

Arapski jezik ima veoma dugu tradiciju. Ovdje smo vidjeli da on sâm, za vlastitu realizaciju, otvara mjesto brojnim novim jezičkim mogućnostima. Jezik se stalno razvija, prilagođava se potrebama govornika. Ono što ga posebno karakterizira, jeste analogijska derivacija zasnovana na etimološkom raspoznavanju leksema i konstruiranju leksičke jedinice. Tu su i paradigmatski oblici, koji su toliko raznoliki da, pored osnovnih značenja, ponekad istovremeno upućuju i na polisemiju i homonimiju. Ova duga tradicija postojanja i njegovanja govornog i pisanog iskaza dokaz je svih tih morfoloških prilagodbi, odnosno sposobnosti jezika da opstoji u različitim vremenima. Širenjem islama na nearapski teritorij, prevođenjem djela pisanih na grčkom jeziku, a kasnije i latinskom, itd., arapski jezik se adaptirao, ponekad nailazio ekvivalent za stranu riječ unutar sebe samoga, a ponekad jednostavno uzimao i(li) davao riječi. Danas smo svjedoci da je engleski jezik lingua franca u svijetu. Riječi iz ovo jezika malo-pomalo ulaze u sve jezike, jer su svi oni podložni utjecajima. Ovdje smo vidjeli da arapski jezik svojim metodama tvorbe riječi može da odgovori raznim jezičkim izazovima, utjecajima, te da još više obogati svoj leksikon.

\footnotetext{
${ }^{51}$ Ibid., str. 743.

${ }^{52}$ Ladislav Zgusta, Priručnik leksikografije, Svjetlost, Sarajevo, 1991., str. 90.
} 


\section{Literatura}

1. Badawi, El-Said, Carter, G. Michael, Gully, Adrian, Modern Written Arabic, A Comprehensive Grammar, Routledge, USA and Canada, 2004.

2. Hodžić, Hajrudin, Arapska vjersko-pravna terminologija u islamu, neobjavljena doktorska disertacija, odbranjena 26.11. 2014. na Filološkom fakultetu u Beogradu

3. Kico, Mehmed, Arapska jezikoslovna znanost, općelingvistička utemeljenja i specifična određenja, Fakultet islamskih nauka u Sarajevu, Sarajevo, 2003.

4. Kico, Mehmed, Ogledi u poetici prevođenja: u svjetlu iskustava o arapskom jeziku, El-Kalem / Fakultet islamskih nauka, Sarajevo, 2009.

5. Jahić, Mustafa, Arapski jezik u islamskim naukama: povezanost $i$ međusobni utjecaji, El-Kalem : GHB biblioteka, Sarajevo, 2012, 536 str.

6. Muftić, Teufik, Arapsko-bosanski rječnik, Rijaset islamske zajednice u Bosni i Hercegovini, el-Kalem, 3. izdanje, Sarajevo, 1997.

7. Muftić, Teufik, Gramatika arapskog jezika, Ljiljan, Sarajevo, 1998.

8. Muftić, Teufik,"O semantici arapskog idafata“, Prilozi za orijentalnu filologiju, 32-33/1982-83, Orijentalni institut u Sarajevu, Sarajevo.

9. Muftić, Teufik, “Osobenosti upotrebe 'kunye'“, Prilozi za orijentalnu filologiju, 27/1977, Orijentalni institut u Sarajevu, Sarajevo

10. Muhtār, 'Umar' Aḥmad, Al-Bahț al-lugiawiyy 'inda al- 'arab, 'Ālam al-kutub, al-Qāhira, 1988.

11. Mujić, Munir, Tropi i figure u arapskoj stilistici, Orijentalni institut, Sarajevo, 2011.

12. Al-Sakākī, Abū Ya'qūb Yūsuf, Miftāh al 'ulūm, Dār al-risāla, Bag̀dād,1982.

13. Șāliḥ, Șubhīin, Dirāsāt fí fiqh al-lug̉a, Dār al'‘ilm li al-malāyīn, Bayrūt, 1979., II izdanje

14. Stetkevych, Jaroslav, The Modern Arabic Literary Language: Lexical and Stylistic Developments, Georgetown University Press, Washington D.C., 2007.

15. Zgusta, Ladislav, Priručnik leksikografije, prevod i predgovor: Danko Šipka, Svjetlost, I izdanje, Sarajevo, 1991. 
Mersiha Causevic, BA

\section{METHODS OF ENRICHING THE LEXICON OF ARABIC LANGUAGE}

\section{Abstract}

Language development is a product of cultural and civilizational heritage of its speakers. Arabic language has developed first through poetry and oral tradition of preislamic Arabians, then through sustained effort to interpret the Quran and Hadith, the two main sources of religion Islam.

Certain methods are required for language development that correspond to the structure of language. In Arabic language they are analogical (qiyas), and are specific for Arabic, as a Semitic language, because they are focused primarily on the etymology (ishtiqaqq), or on the etymological derivation, at the root of the word as the specificity of the language. There are also paradigmatic forms $(f, ', l)$, based on the root of the word with an added affixation. Other methods are: contamination (naht), allegorical meaning (magaz), affixation with an existing word, annexation ('ị̂āfa), borrowing foreign words (iqtirād), and their adaptation to the Arabic language (ta'rib). All these ways of word formation contribute to the increase of the Arabic language vocabulary.

Keywords: method, word formation, derivation, root, paradigm, contamination, arabization, allegorical meaning, suffix. 


\section{الأستاذة مرسيهة تشاؤوشفيتش'}

\section{طرق إثراء معجم اللغة العربية}

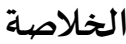

تنمية اللغة هي نتيجة للتراث الثقافي والحضاري لأهل اللغة. تطورت اللغة العربية قبل كل شيء عن طريق الشعر وروايات العرب الشفهية قبل الإسلام، ثم عن طريق السعي الدؤوب لشرح القرآن والحديث، أهم أسس دين الإسلام. لا بد لتنمية اللغة من وجود مناهج معينة تناسب بنية اللغة، وهي في اللغة العربية قياسية وهي خاصية بالعربية باعتبارها لغة بلة

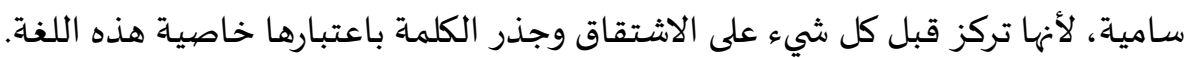

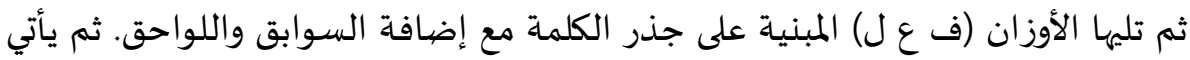
النحت والمجاز والإضافة والاقتراض والتعريب. جميع هذه الطرق لتوليد الكلمات تساهم في

زيادة مفردات اللغة العربية.

الكلمات الرئيسة: المنهج، توليد الكلمات، الاشتقاق، الجذرد، النموذج، النحت،

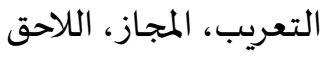

' الأستاذة في كلية التربية الإسلامية في بيهاتش 